どの2 次的変化がないことによるものと考えられる。

一方，PVP に対しては錯會体はSDS とともに，高分子上に ミセル状をたはこれに類似した状柋（以後ミセル的と略す）で 䀠着するものと考えられるき。したがってこの吸着した部分では SDS 搌度が高くなったと同じ効果を示し，錯合体は別の状態ま たは組成になる（たとえば SDS が DA を可溶化したような状 態)。これにともなって TBの錯合体に対する相互作用も変わり， これがスペクトルの変化となって現われるすのと考点られる。こ 円スペクトル变化については別に高級アルコールを用いて詳細に 検討してある2)。極性物質の遧いにより鍇合体の安定性に差異を 生じ，たとえば $\delta$-錯合体をつくるものでは SDS-DA 錯合体は 安定であるが，SDS-ドデカン酸錯合体は不安定である1。錯合 体の安定性の大小はそのまま PVP の影䈍の受けやすさと関係が あるらしく，ここですドデカン酸はDAよりスペクトルの変化が いちじるしい。

PVS ではそれ自身が波長 $530 \mathrm{~m} \mu$ 付近にメタクロマジー带を 有するむので複雑ではあるが， $\alpha-, \beta$-帯が生じないことからし て, SDS または錯合体の PVS へのミセル的な吸着は起りにく いと考えられる。これは PVA の場合と同様に粘度, 電尊度など の結果からも裏づけられる。

PVP の浱度が増大するにともない，スペクトルの $\alpha-\beta$-帶 が㩆著になる。これは高分子濃度の增大にとむない吸着が堌加す るためであろう。PVA や PVS ではその濃度変化はスペクトル に影響を与えない。

スペクトルからの知見をいっそう雅実にするため可溶化その他 の測定を行ない，繁雑さをさけるため $\mathrm{C}_{11} \mathrm{H}_{23} \mathrm{X}$ としてはすっぱ ら DA を使用した。高分子の共存しない界面活性戍溶液に DA
などの極性物質を可溶化させると，界面活性削の炭化水素などに 刘する可溶化能は堌進するることが知られている。高分子への SDS の吸着がミセル的で，とくにDAなどがこれに可溶化され ていると考えられる状態ならば，上述の場合と同様に Y-OB K 対する可溶化能が増進すると期待される。SDS の低䟴度におい て PVA では DA が共存してもほとんど可溶化量が堌大しない のに対し，PVPでは明らかに増大しているのはこの考えを支持 するものであろう。

第3 報8ににおいて界面活性埥の高分子人の吸着には界面活性绪 の親水基の荷電の状態が大きな影鄉を与えることをのべた。錯合 体は SDS とは荷電の状態が異なることが考えられる。このよう な性質をもった錯合体は SDS とは吸着に対する挙動む変わり， 錯合体があるいは SDS が佂先的に高分子に吸着することが考え られる。もし錯合体が優先的に高分子に吸着するならば，高分子 上の荷電密度は SDS のみが吸着した場会と異なるであろうから 粘度的挙動*2において両者になんらかの差異があらわれると考え られるが，いずれの高分子に沶いてる，DA の影嚮はほとんどみ られないことから錯合体が SDS に優先して高分子に吸着するこ とはないと解秋される。SDS の電導度においても高分子の共存 の影響とＤA のそれとは加成的であって，相乗効果はみられな い。これも SDS のみがあるいは錯合体が優先的に高分子に樶着 するものでないことを示するのと考えられる。

7) H. B. Klevens, Chem. Rev. 47, 1 (1950).

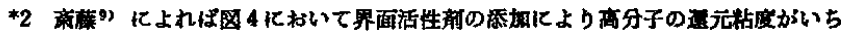

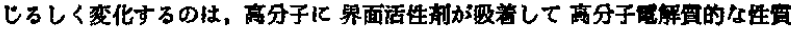
を持つようになるためである。

8) 丸因, 日化 83, 786 (1962).

9) S. Saito, Kolloid-Z. 128, 154 (1952)

\title{
親水鎖の長さの異なるポリオキシェチレンドテシルエーテルの唂液の界面化学的性兵*1
}

\author{
(明和 36 年 12 月 25 日受理)
}

丸田稂†

親水性部分の大きさの異なるポリオキシェチレンドデシルェーテルのイェローOBに対する可溶化能定測定した。可溶化量一界

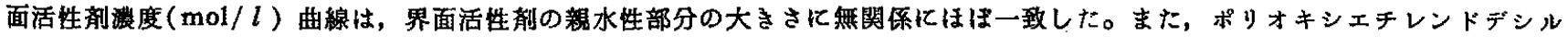
エーテルの水溶液の表面張力扰よび起泡性を测定した。オキシェチレン基が 10〜15 mol 程度まではオキシェチレン基の增大とと るに表面張力の低下率も大きくなるが，15～20 mol 程度以上ではかえって低下率は小さくなった。起泡性はオキシエチレン基が 20〜25 mol 程度のとき取大觉示した。とれらの結果から親水性部分の増大にともなう高分子性の出現について論した。

また，ポリオキシェチレンドデシルェーテルとポリビニルピロリドンまたはポリビニルアルコールとの溶液の可溶化能，粘度な

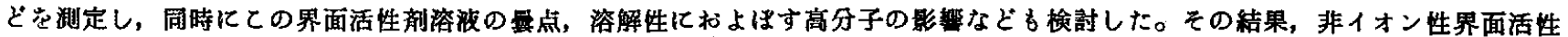
㓮が高分子と相互作用すると考えられるような現象は瑟められなかった。

\section{1 緒賈}

界面活性㓣はその分子内に親水性部分を蹯水性部分とを有し， 両者のバランスが適当にとれている必要があることは周知のとと である。非イオン性界面活性绪（以下，非イオン活性绪と略記） の疎水性部分を一定にたもち，親水性部分を増大していくと当然

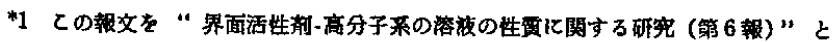
する。

†花王石愉侏式全社研究所, 東京都量田区吾炼即
種々の性質もこれにとるなって変化する。このような親水性-踈 水性のバランスの変化にともなう性質の変化のほかに, 親水性を 大きくすることによる高分子性の出現が問題になる。この点につ いてポリオキシエチレンドデシルエーテルを用いてイエローOB に対する可溶化能，表面張力および起泡性から検討した。

またさきに可溶化の結果》から非イオン活性削は高分子とは相 互作用しないことを報告したが，今回はさらに粘度，曘点および

1) 丸田，日化 8s，786 (1962)， 
溶解性などから高分子との相互作用の有無を再検討した。

\section{2 実験および結果}

\section{1 試 料}

ポリオキシエチレンドデシルエーテル(PODE) : オキシェテレ ンの平均重合度が種々異なる PODEをブタノールー水溶媒で分配 法2により精製した。

ポリオキシェチレンノニルフェニルエーテル(PONE): オキシ エチレンの種々の平均重合度を有する PONE を PODE のとき とまったく同様な方法で精製した。

ドデシルポリオキシエチレン硫酸ナトリゥム(DPOS)：第 3 報 記載1と同一の試料（オキシエチレンの平均重合度 3.0$)$ 。

ポリオキシエチレン: カルボワックス 1000 およびカルボワッ クス 4000 を使用した。オキシェチレンの平均重合度はそれぞれ 約 23 および 91 であった。

ポリビニルピロリドン(PVP), ポリビニルアルコール(PVA): 第 2 報》に記載と同一の試料, PVP および PVA の重合度はそ れぞれ 1440 および 1700 であった。

\subsection{PODE の可溶化能}

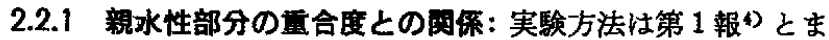
ったく同様である。PODE の可溶化能は濃度を $\mathrm{g} / 100 \mathrm{ml}$ で表 わすと，親水性部分，すなわちポリオキシエチレンの重合度の増 加とともに減少した。ポリオキシェチレンはほとえど可溶化能を 示さなかった(図 1，PODE のあとに付記した数字はオキシェチ レンの平均付加モル数を表わす。以下同様)。図 1 の横軸の $\mathrm{g} /$ $100 \mathrm{ml}$ を mol $/ l$ に畵きかえると, 図 2 のようにオキシエチレ

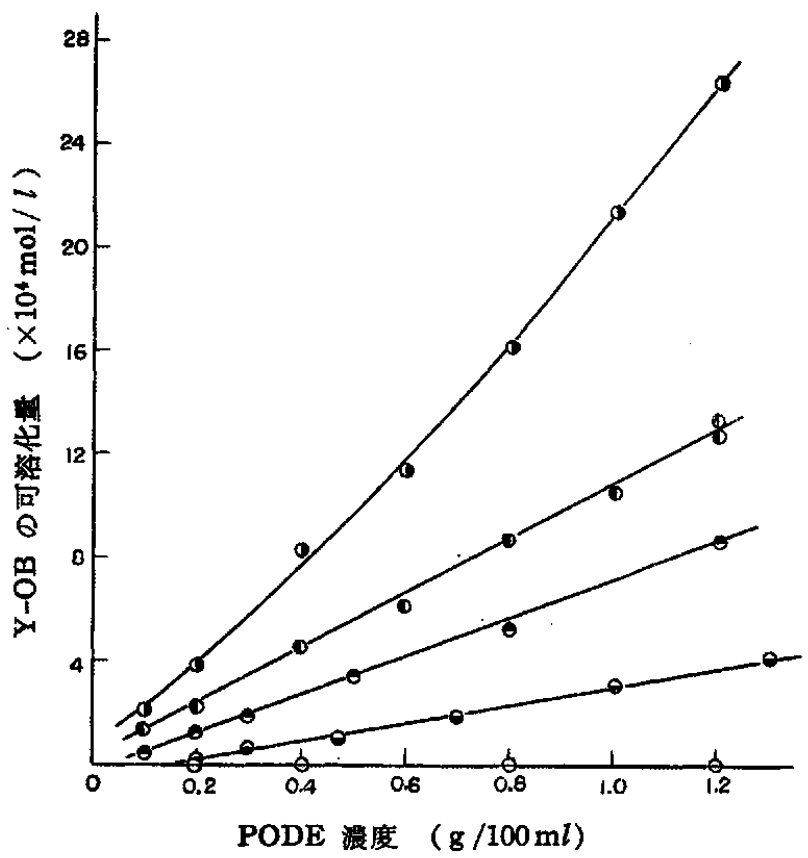

温废 : $30^{\circ} \mathrm{C}$

( PODE-7.6, $D:$ PODE-20.4, $\odot$ : PODE-38.6

: PODE-67.3, O : ポリオキシェチレン

四 1 PODE のオキシェチレン部分の重合度と 可溶化能との関係 (1)

2) 中川, 中田, 工化 59, 710 (1956).

3) 丸田, 目化 83,782 (1962).

4) 丸困，日化 83,395 (1962).
ンの付加モル数に無関係に大体一致する傾向がみられる。

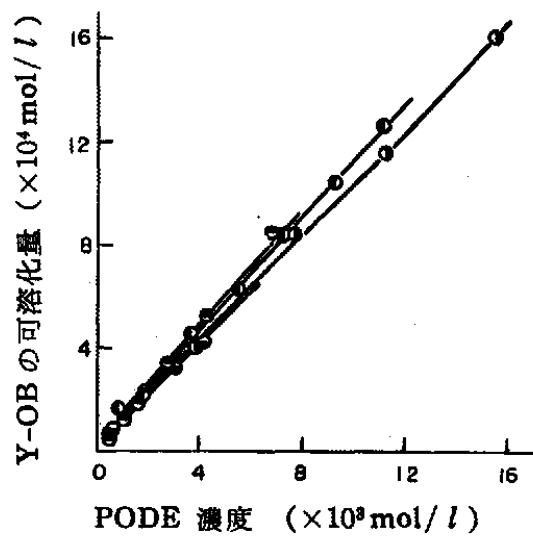

記号は図 1 亿同し

目 2 PODE のオキシェチレン部分の重合度と 可溶化能との関係 $(2)$

2.2.2 高分子との相互作用：PODE に PVP $(0.30 \mathrm{~g} / 100 \mathrm{ml})$ を加立て高分子添加による可溶化能の堌隇を調べたが, 商分子無 添加の場合といずれるほとえど同一で可溶化曲線には変化が認め られなかった。DPOS のときは PVP の添加により可溶化能は 增大したが，SDS のときにくらべてその相乘効果の程度は小さ かった(図3)。

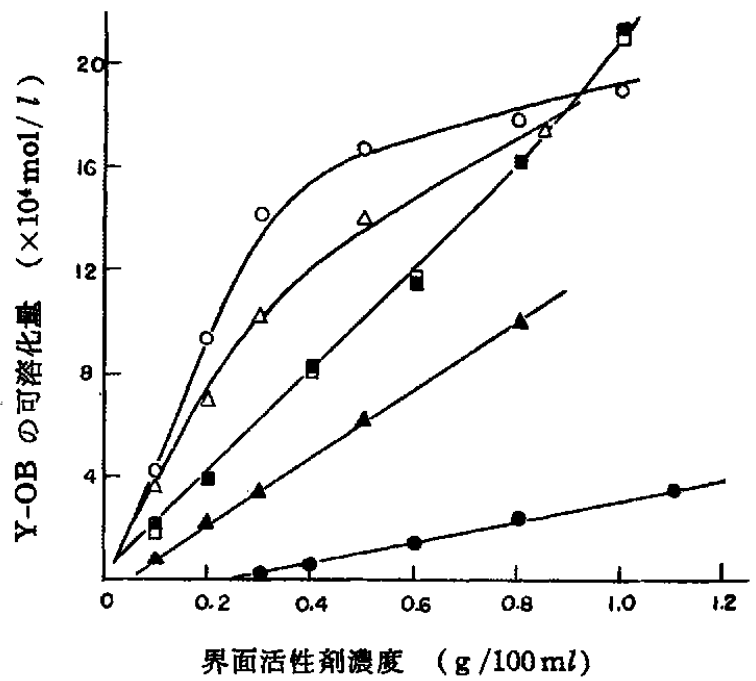

温度 : $30^{\circ} \mathrm{C}$

: SDS, $\triangle$ : DPOS, $\mathbf{0}$ : PODE(界面活性成のみ),

$0:$ SDS, $\triangle$ : DPOS, $\square:$ PODE(PVP $0.3 \mathrm{~g} / 100 \mathrm{ml}$ 源加),

図 3 界面活性剂の可溶化能に打よはす PVP の效果

\subsection{PODE の表面張力}

オキシエチレンの平均重合度が異なる種々な PODE について 表面張力一浱度曲線を求めた。表面張力は $30^{\circ} \pm 0.05^{\circ} \mathrm{C}$ で滴重法 によって測定した。結果はすべて Harkins-Brown の補正らを した。界面活性用の水溶液の㤗面張力が㭙間とともに徐々に変化 することはよく知られているのでの7，この効果についてまず検討 したが,ここでは中川らきと同様に 30 秒に 1 滴の割合で液滴を 形成した。結果を図 4 にあげた。

5) W. D. Harkins, F. E. Brown, J. Am. Chem. Soc. 41, 499 (1919),

6) A. P. Brady, J. Phys. \& Colloid Chem. 33, 56 (1949).

7) M. Quintin, P. Biro, Compt. rend. 238, 471 (1954).

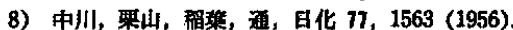


オキシエチレン基が 10〜15 mol 程度まではオキシエチレン基 の増大ととむに表面張力の低下率む大きくなるが, 15〜20 mol 程 度以上ではかえって低下梀は小さくなる。

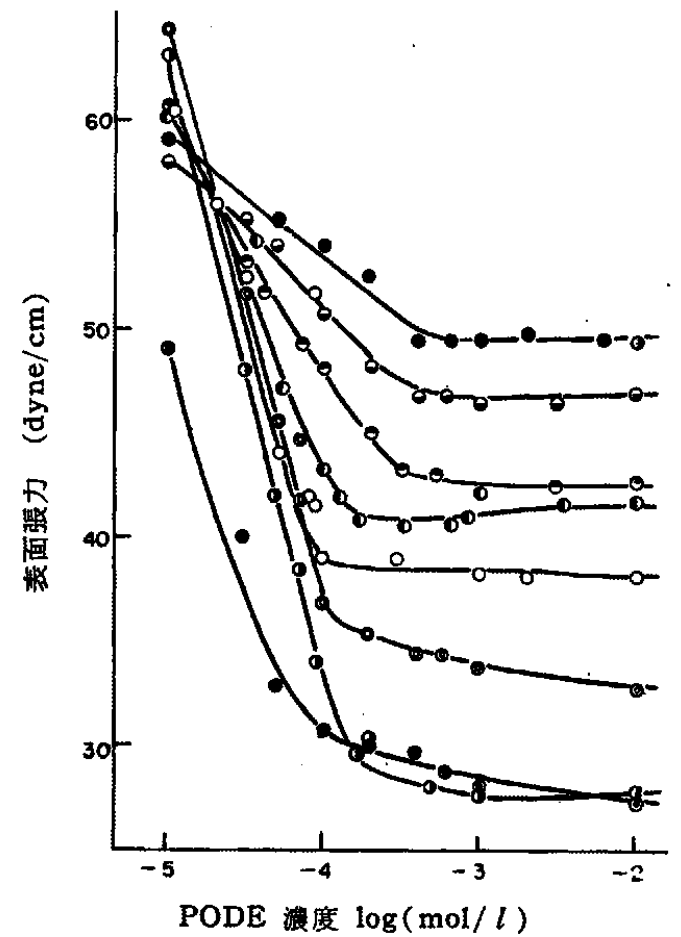

O: PODE-6.2, (O): PODE-7.6, ○ : PODE-10.6

(1) : PODE-15.8, D : PODE-20.4, : PODE-27.1

$\ominus$ : PODE-38.6, $\odot:$ PODE-67.3, 渴度: $30^{\circ} \mathrm{C}$

図 4 PODE の表面張力

\subsection{PODE の起泡性}

$1.0 \times 10^{-3}$ および $1.0 \times 10^{-4} \mathrm{~mol} / \mathrm{l}$ の濃度で起泡力を測定し た。起泡力は Ross-Miles 法りにしたがい, $30^{\circ} \pm 0.5^{\circ} \mathrm{C}$ で測定 した。図 5 には落下直後の泡高とオキシェチレンの付加モル数と

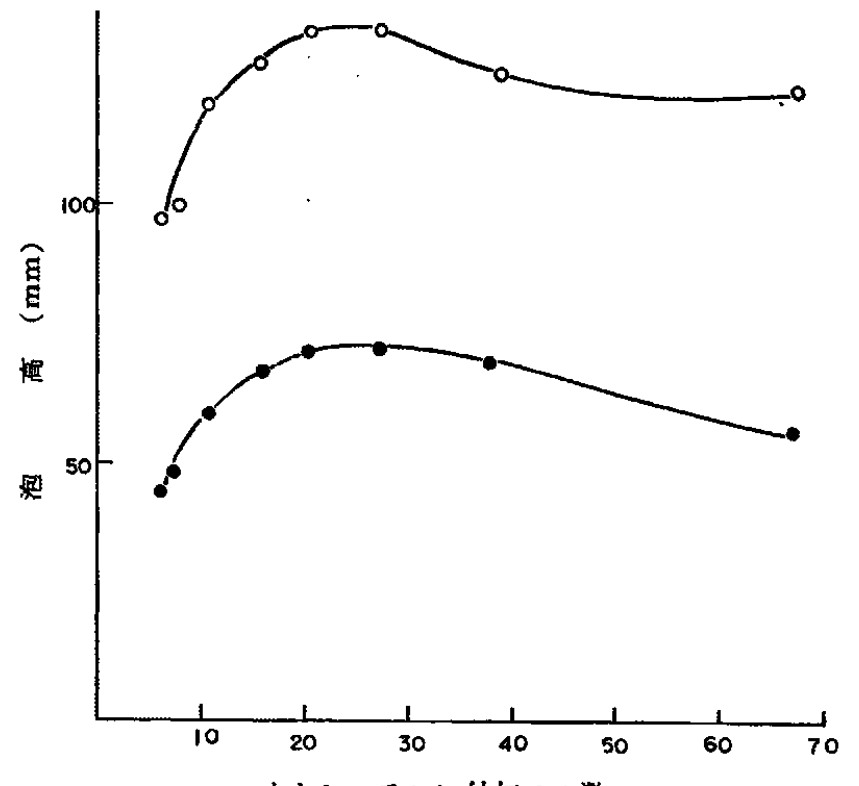

オキシェチレン付如モル数

$O: 1.0 \times 10^{-3} \mathrm{~mol} / l, \bigcirc: 1.0 \times 10^{-4} \mathrm{~mol} / l$, 温度 $: 30^{\circ} \mathrm{C}$ 図 5 PODE の起泡力

(9 J. Ross, G. D. Miles, Oil \& Soap 18, 99 (1941).
の関係をあげた。

オキシェチレン基が 20〜25 mol 程度をではオキシエチレン基 の増大とともに起泡力も增大するが, これ以上では起泡力は徐々 に減少する。すなわち，オキシエチレン基が $20 \sim 25 \mathrm{~mol}$ 程度の とき起泡力は最大を示守。

\section{5 点亡溜解性}

2.5 .1 高分子の共存が点におよばす影算: 高分子と非イオン 活性绪との相互作用の有無を検討するため，高分子の共存が非イ オン活性郕の最点におよほす影響を調べた。墨点測定は非イオン 活性郕および高分子の浱度がそれぞれ $0.1 \mathrm{~g} / 100 \mathrm{ml}$ および 0.5 $\mathrm{g} / 100 \mathrm{ml}$ 混合溶液について行なった。PODE-14.0 および PO

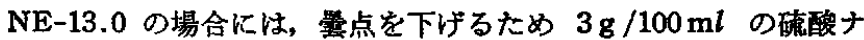
トリウムを添加した。結果は表 1 のとおりである。

\begin{tabular}{|c|c|c|c|}
\hline 活性剂高分子 & 無添加 & PVP & PVA \\
\hline PODE-6.5 & $\begin{array}{l}39.6 \\
(38.0)\end{array}$ & $\begin{array}{l}38.0 \\
(36.0)\end{array}$ & $\begin{array}{l}37.4 \\
(35.4)\end{array}$ \\
\hline-14.0 & $\begin{array}{l}88.0 \\
(86.0)\end{array}$ & 87.5 & $\begin{array}{l}86.8^{(3)} \\
(84.5)\end{array}$ \\
\hline PONE-8.8 & 40.3 & $\begin{array}{l}39.9 \\
(36.7)\end{array}$ & $\begin{array}{l}38.0 \\
(35.6)\end{array}$ \\
\hline-13.0 & $\begin{array}{l}72.3 \\
(71.0)\end{array}$ & $\begin{array}{l}71.5 \\
(70.2)\end{array}$ & $\begin{array}{l}71.0^{(2)} \\
(69.5)\end{array}$ \\
\hline
\end{tabular}

(界面活性都渡度, $0.1 \mathrm{~g} / 100 \mathrm{ml}$ 高分子浱度, $0.5 \mathrm{~g} / 100 \mathrm{ml}$ ) 注 a）硫酸ナトリウムが共存する埸合, $60^{\circ} \mathrm{C}$ 付近飞韭常に 薄い濁りを生じたが，ととではさらに白溜した温度を すって薷点とした。

温度を上异させた場合と下降させた場合とでは一般に暴点は異 なった值を示し，上昇させた場合の方か゚ $1^{\circ} \sim 2^{\circ} \mathrm{C}$ 高い值を与え る。カッコ内は下降させた場合の値である。表 1 から明らかなよ うに, 高分子の添加はごくかずか異点を低下させ, PVA はPVP よりその傾向がわずか大きいようである。

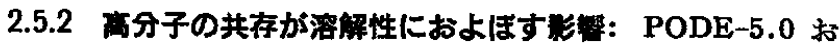
よび PONE-5.0は水に不溶で分散して白濁したが，乙れに高分 子を添加して，白濁の程度の増減を観察した。高分子の添加はわ ずかながら白濁の程度を増加させ，PVA は PVP よりその傾向 がわずか大きいようであった。

2.6 粘 度

PVP 濃度を $0.2 \mathrm{~g} / 100 \mathrm{ml}$ 一定とし, これに、種々の濃度の PODE-7.6 を加えて, $\eta_{\mathrm{sp}} / C_{\mathrm{p}}$-PODE 濃度曲線を求めた。ここ で $C_{\mathrm{p}}$ は PVP の濃度 $(\mathrm{g} / 100 \mathrm{ml})$ を表わす。図6 亿示すように

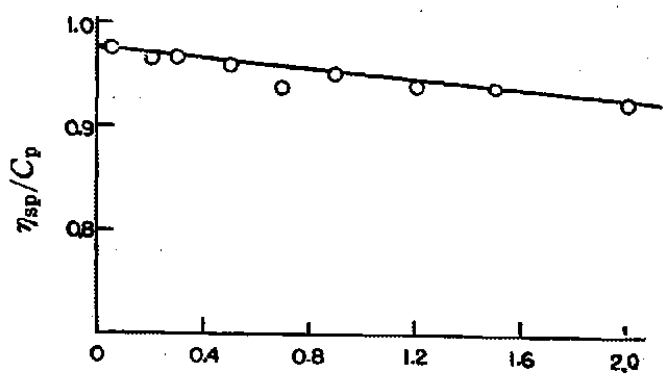

PODE 灌度 $(\mathrm{g} / 100 \mathrm{ml})$

PVP 浱度 $: 0.2 \mathrm{~g} / 100 \mathrm{ml}$, 温度 : $30^{\circ} \mathrm{C}$ 図 6 PVP の $\eta_{\mathrm{sp}} / C_{\mathrm{p}}$, PODE 惯度の影望 
両者間には相互作用が認められない。PVAについてもほとんど 同様の結果が得られた。

\section{3 考察}

\section{1 高分子性の出現}

因 1 は PODE 祳度を $\mathrm{g} / 100 \mathrm{ml}$ で表わした場合の Y-OBの 可溶化量-漲度曲線であるが, 浱度を $\mathrm{mol} / \mathrm{l}$ 亿㥜きかえて表わ す之図 2 のように親水性部分の大小纪無関係红各曲線は大体一致 する。すなわち,PODE $1 \mathrm{~mol}$ あたりの可溶化能はオキシェチレ ン鎖の重合度に関係なく大体一定であるといえる。中川ら ${ }^{100}$ は， エステル型のポリオキシェチレン系非イオン活性削のスダン(面) に対する可溶化能は親水基の短いものほど大きいことを報告して いるが，ここではそのような傾向は認められない。Y-OBのよう な油溶性色素は活性戍のミセル内部に可溶化されるむのと考元ら れる11。またアルキル基泣るセル内部集まっている11。したが って可溶化伩してはアルキル基が必要であって，PODE のポ リオキシエチレン鎖は単に親水性を持たせるだけの役割しかなさ ないむのと考えられる。ポリオキシェチレン恃重合度に関係なく 可溶化能を示さないことからむこの考え方が異つけられる。

伊勢村ら ${ }^{12)}$ 赔水基の長さの異なるポリ-DL-アラニンドデシ ルアミドにおいて，ポリーDLーアラニンの重合度がある值以上にな ると重合度の增加とともに高分子的な性質が現われるようになる ことを表面張力の測定から認め，この 1 種の臨界点ともいうべき 重合度は 10〜15 であることを報告している。また，ての高分子 性の出現は分子内で親水性部分の占める割合が重合度の堌加にと もなって相対的に大きくなり，蹯水性部分の寄与が堿少するため である。つまり，親水性部分のみからなる重合物の性質に近づく ためであると考えられる。しかし現在の場合は，親水基の堌大に とあなう高分子量の PODE が Y-OB を可溶化しなくなるよう な,すなわちポリオキシエチレン自身の特性を示すような重合度 は, 可溶化の実験からは認められなかった。

小田ら ${ }^{18}$ は PONE の親水性部分の增大にともないその溶液の 表面張力は単調に堌大する之述べている。一方, 川村ら ${ }^{19}$ は PO NE, PODE などに颃いて親水性部分を増大していくと比表面張 カに極小がみられることを認めた。Wachs ら ${ }^{15}$ ) よびTween*2型の非イオン活性削の混合率をかえて一連の HLB 価の溶液をつくり，この溶液と炭化水素との界面張力を測定した。 その結果, 界面張力の極少を示主 HLB 価があることを見いだし た。PODE では親水性部分の増大にとひない HLB 洒る堌大す る。図 4 に示したように PODE の親水性部分を増大していくと， オキシェチレン基 10〜15 mol おたりで表面張力の極小がみられ る。この極小を経てからの表面張力の上昇は, PODE 分子中で のポリオキシエチレン部分の占める割合が大きくなるため鄱水性 部分の奇与が小さくなり, 高分子としてのポリオキシエチレン独 自の性質を示し始めるためと解䐆される。これはポリオキシエチ

10) 中!ll, 粟山, 通, 日化 77,1573 (1957).

11) M. E. L. McBain, E. Hutchinson, "Solubilization" Academic Press p. 45 (1955).

12) T. Isemura, S. Ikeda, F. Tokiwa, J. Noguchi, Bull. Chem. Soc. Japan. 34, 1236 (1961).

*2 墑品名, Atlas Powder Co.

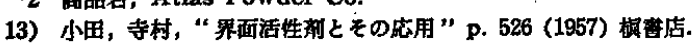

14) 俰村, 南, 油化禁 1, 26 (1952).

15) W. Wachs, W. Reusche, Fette, Seifen, Anstrichmittel 62, 803 (1960).
レンが可溶化能, 表面張力低下能，起泡性をほとんど示さない事 実からも当然考えられることである。

Wrigley ら ${ }^{16)}$ 扰よび Fineman ら ${ }^{17)}$ はポリオキシエチレンア ルキル（また牥ルキルアリル）エーテルの親水性部分の大きさ を変化させた場合，この変化にともなって起泡性む変化し，オキ シエチレン基の重合度がある值で起泡性が極大を示すことを認め ている。Fineman ら ${ }^{17}$ は起泡性が極大に達する前の低起泡性住 ポリオキシエチレン基が小さく，界面活性骩が十分な溶解性をる っていないためであると述べている。しかし，起泡性が極大を示 す理由については説明を加えていない。この起泡性に極大がみら

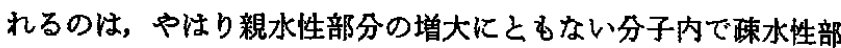
分に比較してポリオキシエチレン部分の性質の寄与が顕著にな り，はじめ界面活性を增すがさらに親水性部分が增大すると，高 分子性が出現してくるためであるう。

\section{2 非イオン活性郕と高分子との相互作用}

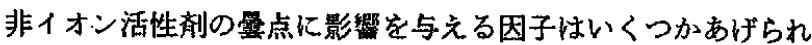
る。硫酸ナトリウムなどの電解質およびフェノールなどの極性物 質は㟟点を低下させるが，ドデシル硫酸ナトリウム (SDS) など の陰イオン性界面活性削技よびドデカンなどの炭化水素は雲点を 上异させる18)。電解質による眎点低下の効果は親水基と水との水 秦結合に影響を与えるためであり，まだ極性物颃による効果はこ れが界面活性削のるセルの親水部に可溶化されることによる。一 方，露点上昇の効果は添加物が非イオン活性削と混合るセルのよ うな 1 種の錯合体を形成するためである ${ }^{183119 \% 。 ~}$

陰イオン性界面活性㓱の水への溶解度柱適当な高分子の添加に よっては增大することが見いだされており20)，これは界面活性削 と高分子との間で錯合体を形成することに起因すると考えられて いる。これと同样に，もし PODE が PVP または PVA と相 互作用して錯合体を形成すると仮定するならば，曔点は高分子の 添加により上昇することが期待される。しかるに表 1 のように高 分子の添加は量点をごくわずかではあるが低下させる傾向さえあ る。この䨘点の低下する原因については前述のように添加物が親 水基と水との水素結合に影響する場合と, 化される場合とがあるが， PVP や PVA のような高分子の添加 によるごくかずかの霞点低下は上のいずれに属するか性判でき ない。また, PODE はオキシェチレンの重合度が小さいとき水 に分散して白㵋または微濁するが，むし高分子之相互作用して錯 合体を非成するならば，高分子の添加により透明に溶解するかま

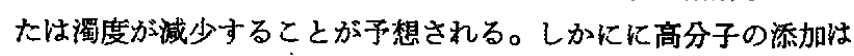
ごくわすがであるが濁りの程度を增大させる。

粘度および可溶化の結果からは PODE と高分子との錯合体の 形成は認められない。それゆ元擂点低下, 罯り增加の現象はPO DE 倍分子がなえらかの影響を与えるにしても，高分子との錯 合体形成によるるのでないことを示していると考えられる。

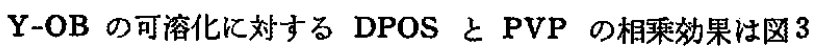
のように SDS と PVP のそれょり小さい(界面活性詴単独では DPOS の方が SDS より大きい)。これは怰オキシエチレン基

16) A. N. Wrigley, F. O. Smith, A. J. Sarton, J. Am. Oil Chemists' Soc. 34, 39 (1957).

17) M. N. Fineman, G. L. Brown, R. J. Myers, J. Phys. Chem. 56, 963 (1955).

18) W. N. Macley, J. Colloid Sci. 11, 272 (1956).

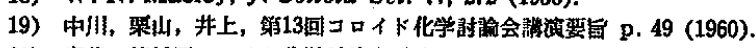

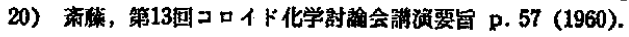


が高分子との錯合体形成を妨げるむのであるという考えを支持す のものであろう。水絜結合によって, PVP や PVA と PODE の親水基が結合する可能性が考えられるが，これが起らないのは ポリオキシエチレン基の 立体的障害のためであろうと考えられ る。るっとも, PODE はポリオキソニゥム化合物を形成すると
考えられており21)，ら-電位の測定からも弱カチオン性を帯びてい ることが認められている22)。また PVP のラクタム部分も同椂に カチオン性であるので PODE が PVP に結合しないのは弱い雪 気的反ぱつのためもあると考えられる。

21) B. Wurzechmitt, $Z$. anal. Chem. 130, 105 (1950)

22) W. Kling, H. Lange, Kolloid-Z. 127, 19 (1952).

\section{アインタクチックポリプロピレンの六方晶変隹と示差熱分析}

(昭和 37 年 2 月 21 日受理)

粟屋裕

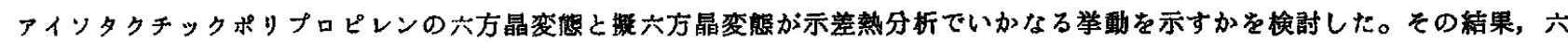

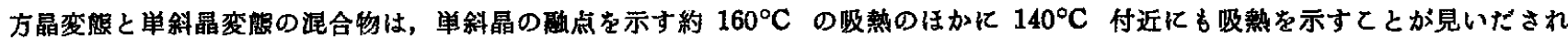
た。後者は Tolchinski らが別に見いだして,シンシオタクチックポップロピレンの期点とみなしたものと一致する。またX線回 折で六方晶変態が見いだされないのに，示差熱分析では $140^{\circ} \mathrm{C}$ の䏜熱がみられる試料も生にた。かかる試料も反射X線回折では

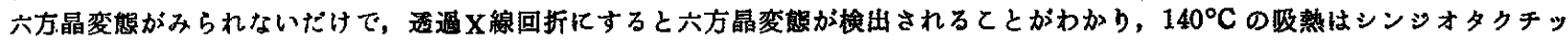

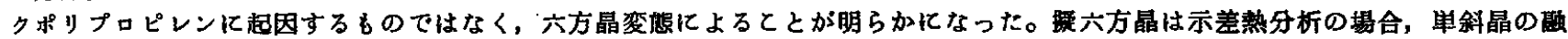
点による吸熱しか示さなかった。

\section{1 緒 量}

Keith らはアイソタクチックポリプロピレンには, 単斜, 擬六 方 (スメクチックポリプロピレンとよばれる) の変態のほかに六

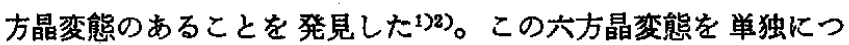
くることは困難であるが，とくにアィソタクティシティの高いポ リプロピレンは六方晶変態を生じや寸いので，このような材料を 用いて，かなり多量に六方晶変態を含む試料をつくり， $\mathbf{X}$ 線回折 で六方晶を確認した上で，示差熱分析にかけて見た。またこの六 方晶変態が生じやすい条件を検討し，これによって六方晶変態の 生成機構を考察して見た。

\section{2 実験}

\section{1 試料および装監}

2.1.1 試 料: ポリプロピレン Avisun-1014。

2.1.2 装絸： $\mathrm{X}$ 線回折装置；ガイガーフレックス, ラウエカメ ラ(理学電機製)。X線管；封入管, Cu ターゲット(Philips 製), $\mathrm{Ni}$-フィルタ使用。示差熱分析装置; 自記式, 中温型 $\left(500^{\circ} \mathrm{C}\right)$, ニッケルブロック，白金セル使用(岛津 DT-10 型), 測定蔡囲合 窝素。

\section{3 実馱方法}

ポリプロピレンを $160^{\circ}, 180^{\circ}, 210^{\circ} \mathrm{C}$ に溶融, ただちに, あ るいは 30 分間溶融状態にたもったのち， $20 \mathrm{~kg} / \mathrm{cm}^{2}$ あるいは $100 \mathrm{~kg} / \mathrm{cm}^{2}$ の圧力でプレス成形して, 厚さ約 $1 \mathrm{~mm}$ の板をつ くった。

これらの試料のX線回折をガイガーフレックスで調べ，六方晶 変驡の有無を調べたのち，この試料の一部を細断し， $\alpha$ ーアルミ

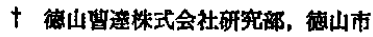

1) F. J, Padden, H. D. Keith, J. Appl. Phys. 30, 1479 (1959).

2) H. D. Keith, F. J. Padđen, N. M. Watlter, H. W. Wyckoff, ibid. 3日, 1485 (1959).
ナと混ぜて，示差熱分析にかけた。示差熱分析は䄪 $5^{\circ} \mathrm{C} / \min の$ 速度で昇温した場合を測定した。X線回折で六方晶変態がみられ ないのに，示差熱分析に異常の見いだされた試料は，さらにラウ エカメラを用い， $\mathrm{Cu}-K_{\boldsymbol{\alpha}}$ 線による透過 $\mathrm{X}$ 線回折を調べてみた。

急冷および延伸によって懒六方晶試料をっくり，そのX線回折 と示差熱分析を行なった。

また六方晶変態の試料を加熱して, 六方晶変態の消失する温度 をX線回折によって求めた。

\section{3 結果}

$\mathrm{X}$ 線回折の結果を図 1 に, 示差熱分析の結果を図 2 にかかげる。 No. 1 は $210^{\circ} \mathrm{C} に 30$ 分たもったのち, $20 \mathrm{~kg} / \mathrm{cm}^{2}$ の圧力でプ レス成形したもので, 結晶形は単斜晶, 示差熱分析ては単斜晶ポ リプロピレンの融点を示すと思われる吸熱ピークが $160^{\circ} \mathrm{C}$ 付近 に認められた。No. 2, No. 3 は $180^{\circ} \mathrm{C}$ に加熱して, すぐプレ ス成形したるので，六方晶を含んだ単斜晶試料である。これは $160^{\circ} \mathrm{C}$ 付近の吸熱のほかに $140^{\circ} \mathrm{C}$ 付近にも吸熱がみとめられた。 No. 4 注 $160^{\circ} \mathrm{C}$ k加熱 $20 \mathrm{~kg} / \mathrm{cm}^{2}$ の圧力で成形したものであ るが，これにも六方晶があらわれ，示差熱分析では，140 $\mathrm{C}$ の吸 熱を示した。X線回折で六方晶を含む単斜晶ポリプロピレンであ ることが確認された試料牥いずれる $140^{\circ}, 160^{\circ} \mathrm{C}$ のの 2 つの昅熱 ピークを示すのに対し，単斜晶 ポリプロピレンはほとんど $160^{\circ}$ C の吸熱ピーク だけしか 示さない。その例外が No.5 である。 これは $180^{\circ} \mathrm{C}, 100 \mathrm{~kg} / \mathrm{cm}^{2}$ の成形試料であるにるかかわらず, $\mathrm{X}$ 線回折は単斜晶であることを示し，示差熱分析では $140^{\circ} \mathrm{C}$ ， $160^{\circ} \mathrm{C}$ の 2 本の吸熱ピークがあらわれた。この試料の透過 X線回 折写真を調べたところ，六方晶ポリプロピレンが存在することが わかった。すなわち, No.5 泣六方晶も存在しているが反射 X線 回折で怯その存在がかからなかったのにすぎい(军真 1)。

No. 6 注急冷によってつくったスメテック試料で，結晶形は椥 